Elaine Jeffreys (2018) Curating philanthropy and socialist governance: the Chinese Charity museum, Museums \& Social Issues, 13: 2, 78-93, DOI:10.1080/15596893.2019.16070

Published online 17 April 2019

\title{
Curating Philanthropy and Socialist Governance: The Chinese Charity Museum
}

\author{
Elaine Jeffreys \\ University of Technology Sydney
}

\begin{abstract}
This paper examines the growing political importance of philanthropy in the People's Republic of China as presented in the Chinese Charity Museum, probably the only nationallevel museum in the world to feature permanent exhibits focused solely on the subject of philanthropy. The paper explains why charitable practices, which purportedly flourished in pre-communist China, “disappeared” during the Mao era (1949-1976), and why philanthropy is now a government-endorsed activity. It then examines the state-prescribed role of Chinese museology and the creation of a charity museum in Nantong City, before investigating the socio-political narrative that frames the Nantong collection. It concludes that the museum's "story" simplifies and elides the significant change in forms of philanthropic institutions and practices in contemporary China, relative to their pre-1949 precursors, but yields new insight into how the Chinese Communist Party is recasting philanthropy as an integral part of socialist culture and state-led welfare provision.
\end{abstract}

Keywords: charity, China, government, museum, socialist, philanthropy

\section{Introduction}

The Chinese Charity Museum in Nantong City in the People's Republic of China (PRC) is probably the only national-level museum in the world to feature a permanent collection of 
Elaine Jeffreys (2018) Curating philanthropy and socialist governance: the Chinese Charity museum, Museums \& Social Issues, 13: 2, 78-93, DOI:10.1080/15596893.2019.16070 Published online 17 April 2019

exhibits focused solely on the history and practice of philanthropy. The museum is doubly unusual because it embodies the resurrection, newfound acceptability and political importance of philanthropy in a communist state where charity was once denounced as a "feudal poison" and "sugar-coated bullet" of the bourgeoisie (Sun, 1994, p. 4). Its opening on 1 September 2016 was timed to coincide with the introduction of the nation's first and longdebated Charity Law, the presentation in Nantong City of the ninth China Charity Awards, and the inauguration of a national Charity Day on 5 September (Chinese philanthropy museum opens to greet 1st Chinese Charity Day, 2016; National People's Congress, 2016a).

How does one create, curate and experience a museum communicating the history and vitality of Chinese philanthropy in a country whose ruling Communist Party once undertook to eliminate most charitable organizations in the name of the political philosophy it espoused? This poses a particular challenge because the revised Law of the People's Republic of China on Protection of Cultural Relics (2007) explicitly states that museums and other institutions shall help the Party-state to build a socialist society by enhancing "publicity and education in the splendid history and culture and the revolutionary tradition of the Chinese nation" (Article 40; see also Article 1).

The paper first explains why charitable institutions and practices, which purportedly flourished in pre-communist China, "disappeared" during the Mao era (1949-1976), and why philanthropy is now promoted as a government-endorsed activity. It then discusses how a national-level charity museum was created in Nantong City and the nature of public communication about that museum, connecting these developments to recent Chinese Communist Party (CCP) discourses on "national" values, and the appropriate configuration of social welfare provision. Finally, it examines the museum collection and the socio-political narrative that frames the exhibits. The paper concludes that in anticipating an "official" view of the history, evolution and role of philanthropy in China, the museum deliberately blurs the boundaries between private charitable actions and public welfare provision to legitimize an emerging approach to public policy that places greater weight on self-guided citizen behaviour.

\section{The government-promoted rise of PRC philanthropy}


Elaine Jeffreys (2018) Curating philanthropy and socialist governance: the Chinese Charity museum, Museums \& Social Issues, 13: 2, 78-93, DOI:10.1080/15596893.2019.16070 Published online 17 April 2019

The founding of the Chinese Charity Museum is an extraordinary event not simply because of the unusual nature of the museum's collection, but because philanthropy is a "new" phenomenon in the PRC, and PRC museums are expected to reflect and advance governmentendorsed views of China's history, traditions and socialist culture (Denton, 2014; Ho, 2018; Lu, 2015). Philanthropy is defined here as "the planned and structured giving of money, time, information, goods and services, voice and influence to improve the wellbeing of humanity and the community" (What is philanthropy, 2018). The terms "charity" and "philanthropy" are often used interchangeably in English and in their Chinese equivalents. However, charity historically involved the localized giving of short-term relief to individuals in need, whereas modern philanthropy arguably comprises more sustained attempts to address the circumstances that make particular populations vulnerable and in need of assistance (Jeffreys \& Allatson, 2015, p. 7).

Following the founding of the PRC under CCP leadership in 1949, the concept and practice of charity fell into disrepute and disuse until the 1990s. Contrary to the views popularized by nineteenth-century Christian missionaries in China, there was a significant albeit fragmented tradition of public welfare and charity in imperial China associated with state-run disasterrelief efforts, and the associational life of clans and guilds and Buddhist and Daoist temples (Simon 2013; Smith 2009). However, after 1949, many pre-communist-era charities were associated with elite groups that became the target of revolutionary hostility - landowning gentry, entrepreneurs, religious leaders, foreign missionaries and "imperialists" (Jeffreys, 2017a, pp. 319-320). Along with the political suppression of these groups, the objectives of the charities to support selected public-interest causes in local communities became inconsistent with the imposition of a new centralized model of governance and welfare provision in accordance with the principles of Marxism-Leninism. Nationalization of industry and the adoption of a planned economy proceeded with the goal of ensuring that basic social services were provided for all citizens through a state-organized system of urban work units and rural agricultural collectives. Marxist politics also dictated the demise of religion, understood as the "opiate of the masses" and a vehicle for superstition and exploitative class relations (Cooke, 2009, p. 128). Buddhist and Daoist associations were placed under the auspices of Party organizations: these affiliations were de-activated when a campaign against “old ideas, culture, customs and habits" started during the Great Proletarian Cultural Revolution (1966-1976), and were not revived until the early 1980s (Cooke, 2009, p. 128). 
Elaine Jeffreys (2018) Curating philanthropy and socialist governance: the Chinese Charity museum, Museums \& Social Issues, 13: 2, 78-93, DOI:10.1080/15596893.2019.16070 Published online 17 April 2019

The People's Daily - the print media voice of the CCP - officially recuperated the Chineselanguage term "cishan", which translates into English as "charity" and "philanthropy", in 1994, around 15 years after the PRC's adoption of market-based economic reforms in December 1978. In an article titled "Rehabilitating Charity", the newspaper noted that a government-organized charity federation had been established to assist aged, disabled and impoverished people who were unable to support themselves, and had no family members to support them (Sun, 1994, p. 4). The newspaper added that charity had been denounced during the (now denigrated) Cultural Revolution period as "anti-revolutionary" and the word "cishan" had been more or less forgotten. However, the practice of helping people in need is both a traditional Chinese and socialist virtue, and hence the PRC should have its own forms of philanthropy and philanthropists (Sun, 1994, p. 4).

The government's endorsement of philanthropy is linked to the reorganization of society demanded by the reform-era introduction of a labour market. Increased demands for mobile labour, and the corollary gradual dismantling of the urban work-units and rural agricultural collectives, which functioned on the basis of a geographically-fixed population, meant that the Party-state could no longer supply the varied range of social services to employees and retirees that had previously been the norm (Jeffreys, 2017a, p. 321). Given its historical commitment to improving the life of the Chinese population, the PRC government had to start creating standardized welfare services that would be made available to all citizens through government, community and private service providers, such as unemployment and retirement benefits, education, healthcare, aged care, disability services, and affordable housing (Carrillo, Hood \& Cadets, 2017). Organized philanthropy became a policy issue in this context.

Since the early 2000s, the PRC government has attempted to enhance social service provision in part by encouraging the expansion of organized philanthropy through national policy. The Tenth Five-Year Plan for National Economic and Social Development (2001-2005) recommended developing philanthropic organizations to strengthen the social security system, especially in the context of ageing population trends (Jeffreys, 2017a, pp. 321-322). The Eleventh Five-Year Plan (2006-2010) advocated expanding the not-for-profit sector, especially organizations supporting education and youth. The Twelfth Five-Year Plan (2011- 
Elaine Jeffreys (2018) Curating philanthropy and socialist governance: the Chinese Charity museum, Museums \& Social Issues, 13: 2, 78-93, DOI:10.1080/15596893.2019.16070 Published online 17 April 2019

2015) proposed using tax incentives to create an inclusive system of registered professional, private and community organizations to alleviate poverty and provide services for orphaned, elderly and disabled people. The Thirteenth Five-Year Plan (2016-2020) recommends developing professional social work and not-for-profits, and especially those that assist aged, disabled, young and impoverished people (Zhonghua renmin gongheguo guomin jingji he shehui fazhan di shisan ge wunian guihua gangyao, 2016).

Since 2005, the Ministry of Civil Affairs has also recognized outstanding philanthropists through a system of China Charity Awards (Jeffreys, 2017a, p. 322). The list of award winners was released annually from 2005-2012 and, following a break in 2013-2014, has become a biennial event, with the 2015 winners receiving awards in September 2016 to coincide with the opening of the Chinese Charity Museum (www.zhcsbwg.cn). Government officials and other individuals receive awards for their philanthropic activities, whereas private and state-sector entrepreneurs are awarded for the extent of their donations. President Hu Jintao became the first senior CCP leader to present philanthropy as crucial to the PRC's development in December 2008, when he gave a speech to announce the recipients of the China Charity Awards following a catastrophic earthquake in May in Sichuan Province. President $\mathrm{Hu}$ called on all Chinese citizens to help create a prosperous and harmonious China by fostering a philanthropic culture (Jeffreys, 2017a, p. 322).

The government promotion of philanthropy in the reform era, especially from the $2000 \mathrm{~s}$ onwards, is confirmed by a search for the keyword "cishan" in the electronic database of the People's Daily between 1 October 1949 and 31 December 2010. The search obtained approximately 3,500 hits, with nearly 90 per cent occurring after 1978. Of the more than 3,100 hits obtained after 1978, the majority (75 per cent) occurred between 2000 and 2010 (People's Daily, 1946-). As these figures suggest, in the wake of policies that decentralized economic management, and raised overall living standards at the expense of widening inequality, a space was created for private and not-for-profit service providers to supplement the government's role in social welfare provision and diminish the potential for social unrest.

The newfound political acceptability and growing importance of Chinese philanthropy is highlighted in a 2014 State Council document, "On Promoting the Healthy Development of Philanthropy", which urges all levels of government to develop through tax incentives a 
Elaine Jeffreys (2018) Curating philanthropy and socialist governance: the Chinese Charity museum, Museums \& Social Issues, 13: 2, 78-93, DOI:10.1080/15596893.2019.16070 Published online 17 April 2019

legally registered not-for-profit sector that will complement government welfare services by 2020 (State Council, 2014). This goal dovetails with the Thirteenth Five-year Plan's aim of eradicating domestic poverty by 2020 , just before the centenary anniversary of the CCP's founding in 1921. That timing highlights the provision of "universal (modest) prosperity" as a feature of the early and current CCP's claims to political legitimacy, although the early regime aimed to realize that goal through state ownership and distribution of resources, rather than through public-private collaborations.

Two laws were introduced in 2016-2017 with the aim of rapidly expanding the PRC's notfor-profit sector, while restricting the role of certain categories of international organizations and donors on the grounds of protecting national security. The PRC's Charity Law came into effect in September 2016, followed by the Law on the Management of Foreign NonGovernmental Organizations' Activities within Mainland China in January 2017 (National People's Congress, 2016a, 2016b). The Charity Law recommends providing tax incentives for domestic foundations, social service organizations and membership associations that meet annual reporting requirements. The law on foreign NGOs requires international NGOs to be registered and established not-for-profits that support PRC public policy. The proclaimed aim of both laws is to create a professional, legally registered and accountable not-for-profit sector that will support the PRC government's social welfare goals, for example, by eliminating poverty and improving the environment (and not funding or participating in illicit political, religious and other activities that endanger national security and ethnic unity). However, critics contend that the foreign NGO law will impede the development of the country's nascent philanthropic sector because it requires international NGOs to register with local public security departments, as is also the case for foreign businesses and residents in China (Feng, 2017).

Hence, unlike Western accounts of philanthropy as an integral part of "civil society", in which citizen activity is assumed to have developed historically either independently of or ideally outside of the operation of government, the PRC's emerging philanthropic sector is embedded within the Party-state system. These links constrain the independent operation of Chinese not-for-profits, and tend to be viewed negatively by those who conceive of private philanthropy as a wedge against state expansionism. Indeed, Anglophone scholars often contend that the PRC's philanthropic sector is too "state-connected" or insufficiently 
Elaine Jeffreys (2018) Curating philanthropy and socialist governance: the Chinese Charity museum, Museums \& Social Issues, 13: 2, 78-93, DOI:10.1080/15596893.2019.16070 Published online 17 April 2019

autonomous and non-governmental (Simon, 2013, pp. xxvii-xliii.). By the same token, government efforts to enhance social welfare through indigenous philanthropy are creating new spaces for new types of social actors and organizations to become involved in government-identified development issues (Jeffreys, 2017).

Despite high-level government support for philanthropy, there is no "official" public communication narrative that contextualizes the current priority placed upon it by the PRC government within China's putative historical tradition of charitable activities. The Chinese Charity Museum helps to fill this gap. It anticipates and shapes such a narrative within the parameters of permissible government discourses on the role of museums, and the nature of national values and aspirations.

\section{The role of PRC museums and the charity museum}

The role of museums in the PRC is to put "politics on display" by presenting governmentpermitted views of Chinese history and culture, the CCP's achievements and goals, and national values and aspirations (Denton, 2014; Ho, 2018; Lu, 2015). This is arguably an accentuated version of conventional museum practice. National museums in Western contexts historically presented state-orientated and often imperialist ways of thinking about the nation, and national culture and identity, in keeping with mainstream political discourse and the exigencies of public funding (McDonald, 2003; Message \& Witcomb, 2015). Nowadays, museums tend to present more diversified and "entertaining" collections that reflect broader source communities and interests, because of changing ideas about and consumer demands of the role of museums and the adoption of commercial funding models.

Chinese museology remains tied to national government planning, despite growing numbers and types of museums. There were only 263 museums in the PRC in 1976; that figure rose to 349 museums by the end of 1978 (Lu, 2015, p. 198). By 2015, the PRC had more than 4,700 registered museums, including more than 1,000 privately-run collections. But most PRC museums are state-owned (76 per cent) and offer free entrance (86 per cent) to around 700 million Chinese citizens each year (Wu, Jiang, Zhou \& Feng, 2016). PRC museums, including specialized, permanent collections such as the Chinese Charity Museum, are viewed primarily as "social" and "socialist" education institutions, even though they 
Elaine Jeffreys (2018) Curating philanthropy and socialist governance: the Chinese Charity museum, Museums \& Social Issues, 13: 2, 78-93, DOI:10.1080/15596893.2019.16070 Published online 17 April 2019

increasingly use public-private funding models and aim to attract audiences by providing educative leisure (Liu, 2016).

The PRC's Sixth Five-year Plan for National Economic and Social Development (1981-1985) stipulated that there should be a museum in every city to "serve the people" by providing educative leisure and "building socialist spiritual civilization" (Guanyu fazhan guomin jingji de di liu ge wunian jihua de baogao, 2009). The concept of "socialist spiritual civilization has been variously defined, originally in terms of an opposition to "decadent" aspects of Western capitalist culture, and more recently in relation to the development of a national civic culture (Gongmin daode jianshe shishi gangyao, 2001). In essence, socialist spiritual civilization is an umbrella term for multiple programmes of government aiming to ensure that the development of the PRC's "socialist market economy" goes hand-in-hand with the advancement of "Chinese" and "core socialist" values; however those values might be defined. Chinese values currently refer to revamped conceptions of Confucian guidelines for ethical behaviour such as displaying "harmony, benevolence, righteousness, courtesy, wisdom, honesty, loyalty, and filial piety" (Zhang, 2013). The core socialist values, as defined at the Eighteenth National Congress of the CCP in 2012, are prosperity, democracy, civility, harmony, freedom, equality, justice, rule of law, patriotism, dedication, integrity and friendship (Du, 2016).

All of the PRC's Five-year Plans for economic and social development from 1986 to 2020 , excluding the Ninth Five-year Plan (1996-2000), have advocated developing museums to socialize citizens via education about Chinese-PRC history, values and aspirations. The Seventh Five-year Plan (1986-1990) recommended building major museums to promote patriotic education, and especially to commemorate the revolutionary struggle associated with the second Sino-Japanese War and the founding of the PRC (Zhonghua renmin gongheguo guomin jingji he shehui fazhan di qi ge wunian guihua (zhaiyao), 1986). The Eighth and Tenth Five-year Plans for 1991-1995 and 2001-2005, respectively, advocated increasing the number of museum-like institutions to promote outstanding national and socialist culture, and to counter the negative aspects of foreign culture (Guomin jingji he shehui fazhan di shiyi ge wunian guihua gangyao, 2001; Zhonghua renmin gongheguo guomin jingji he shehui fazhan di ba ge wunian guihua (zhaiyao), 1991). The Eleventh Fiveyear Plan (2006-2010) proposed developing major tourist attractions such as the National 
Elaine Jeffreys (2018) Curating philanthropy and socialist governance: the Chinese Charity museum, Museums \& Social Issues, 13: 2, 78-93, DOI:10.1080/15596893.2019.16070 Published online 17 April 2019

Museum and National Art Museum of China, and increasing local government investment in the culture industries (Zhonghua renmin gongheguo guomin jingji he shehui fazhan di shiyi ge wunian guihua gangyao, 2006). The Twelfth Five-year Plan (2011-2015) recommended using commercial and not-for-profit models to develop the culture industries, while simultaneously improving access to services, including by providing free entry to public museums, art galleries and libraries (Zhonggong zhongyang guanyu zhiding guomin jingji he shehui fazhan dishi ge wunian jihua de jianyi, 2011). The Thirteenth Five-year Plan (20162020) further advocated improving cultural services and access to public museums, libraries and cultural centres at the city and county level (Zhonghua renmin gongheguo guomin jingji he shehui fazhan di shisan ge wunian guihua gangyao, 2016).

The Chinese Charity Museum offers a unique contribution to the goal of socializing citizens about Chinese-PRC history and values, being located in an economically developing city with historical museology and philanthropic credentials. Nantong lays claim to symbolic capital as the birthplace of the Chinese public museum and has won multiple national-level awards as a Historical Culture City, Seven-Star Charity City, Outstanding Tourism City, Top Ten Ecological Civilisation City, and City with the Most Dynamic Private Economy (nantong.jiangsu.net). Nantong is a prefecture-level city in Jiangsu Province, on the northern bank of the Yangtze River estuary, with a population of around 8 million people (Nantong, 2016). In 1984, Nantong was among the PRC's first batch of 14 coastal cities to be opened to foreign investment, and the city's GDP was ranked nationally at number 21 in 2016. It is located on the historic "Silk Road" and is a part of the revitalized "new Silk Road", being the starting point for the China-Afghan railway line. Nantong is also home to the Nantong Museum (a top-grade national museum described as China's "first" public museum), the Nantong Abacus Museum and Nantong City Museum, and more than 20 protected cultural heritage sites. The Nantong Museum was founded in 1905 by Zhang Jian (1853-1926), a renowned Qing dynasty scholar-official, industrialist, educationalist and philanthropist (Lu, 2014, p. 79).

The Jiangsu.net website attributes the city's success to historical legacy and contemporary innovation, lauding Zhang Jian - the founder of China's first public museum - as the "King of Nantong" (nantong.jiangsu.net). Zhang Jian funded and promoted businesses, schools, libraries, museums and theaters in Nantong, and, following the collapse of the Qing dynasty, 
Elaine Jeffreys (2018) Curating philanthropy and socialist governance: the Chinese Charity museum, Museums \& Social Issues, 13: 2, 78-93, DOI:10.1080/15596893.2019.16070 Published online 17 April 2019

held senior government positions including as Minister of Industry and Commerce. Zhang founded the Nantong Museum initially to show students of a college that he had funded tangible specimens of natural history, fine arts and antiquities; the museum was later opened to the general public (Lu, 2014, pp. 80-83). He also submitted proposals to the Qing court about establishing national museums to glorify Chinese civilization and stop overseas collectors from acquiring Chinese antiquities (Lu, 2014, p. 84).

Located on the site of Nantong's first industrial cotton mill, founded by Zhang Jian in 1899, the Chinese Charity Museum is a communication platform for promoting education and research on indigenous philanthropy. The state-supported museum, which charges no entrance fees, was financed through private donations and funding from central and local government agencies, including the State Council, Ministry of Civil Affairs, Jiangsu Provincial Government and Nantong Municipal Government (www.zhcsbwg.cn/). Reportedly built at a total cost of CNY 278 million (USD 41 million), it hosts a collection of 2,900 items and over 8,300 images in a building on an area of 24,858 square meters; the ground floor area alone is 18,000 square meters (Zhao, 2016). Permission to build the museum was obtained from the Ministry of Civil Affairs in May 2010. A seminar was subsequently hosted in May 2011 by the State Administration of Cultural Heritage in Beijing to discuss the proposed museum collection, which was attended by government officials, academics, and managers and curators of national museums (www.zhcsbwg.cn/). The museum opened in September 2016, after at least five years of collecting artefacts and organizing relevant exhibits and presumably closer to 10 years of planning for the construction of such a museum.

Public communication about the museum in the PRC's state-controlled media has centred on the planning for and launch of the museum, the museum's augmentation of Nantong's status as a cultural heritage city, and the role of philanthropy in promoting socialism. A search for the term "Chinese Charity Museum" (Zhonghua cishan bowuguan) on the China Core Newspaper Full-text Database of the China Knowledge Resource Integrated Database (cnki.net.cn) revealed that the museum was mentioned in around 50 news items between 2011 and 2016. A small number of articles focused on the preparatory seminar for the museum held in 2011 and the museum's opening in 2016 (Ren, 2011; Tao, 2011; Yuan \& Huang, 2016; Zhang, 2011). Other publicity mentions the museum in relation to Nantong's branding as a culture and heritage city (Ding, 2011; Li, 2015; Xu, 2012). The Chinese 
Elaine Jeffreys (2018) Curating philanthropy and socialist governance: the Chinese Charity museum, Museums \& Social Issues, 13: 2, 78-93, DOI:10.1080/15596893.2019.16070 Published online 17 April 2019

Charity Museum is one of more than twenty museums in an area described as a "Model National Public Cultural Service Demonstration Project" (Chen \& Fu, 2015; Wang \& Xu, 2012; Xu, 2012). This means that central government departments have assessed the processes by which the Nantong Municipal Government created, funded and operates these sites as being worthy of emulation by other cities in China.

Other publicity discusses the museum in relation to the government-endorsed role for PRC philanthropy of carrying forward Chinese-socialist culture by assisting the policy goals of eradicating poverty, improving social welfare and advancing socialist spiritual civilization (Jin, 2016; Pan, 2012; Zhang, 2016; Zhang, 2012). Traditional Chinese and core socialist values are described in terms of a willingness to help people in need and thereby contribute to social development (Chen, 2016; Tao, 2011; Yi, 2016). The museum's provision of public education about philanthropy is praised in this context for helping to improve the "human capital" of Chinese citizens (Chen \& Fu, 2015; Wang \& Xu, 2012). Hence the next section details the nature of the museum exhibits and the socio-political narrative that frames the collection.

\section{Exhibiting Chinese philanthropy}

Museum exhibitions are typically organized around a "big idea", in order to focus and guide audience experiences of the displayed collection of artefacts, texts and images, even though visitors may resist the efforts of curators to force them to follow a particular narrative path.

The Chinese Charity Museum is organized around the unfamiliar idea that China has a more than 3,000-year-long history of philanthropy that is rooted in Chinese values and state-led efforts to improve the quality of life of the Chinese people. Carvings, rubbings, images and collections of ancient texts affirm that the philanthropic tenets of universal love, harmony and benevolence are embedded in the indigenous philosophies and religions of Confucianism and Daoism, as well as in Chinese Buddhist and Islamic traditions. Traditional philanthropy is described as being expressed originally through the concerns of emperors and clans to provide populations with relief from natural disasters and famine, and subsequently through the additional activities of intellectuals and entrepreneurs. Modern philanthropy is explained as emerging in the mid-nineteenth century through charitable institutions established by 
Elaine Jeffreys (2018) Curating philanthropy and socialist governance: the Chinese Charity museum, Museums \& Social Issues, 13: 2, 78-93, DOI:10.1080/15596893.2019.16070 Published online 17 April 2019

reform-minded intellectuals and entrepreneurs and Western missionaries, and evolving since the mid-twentieth century, through the development of socialist governance.

The museum's narrative starts with periods corresponding to early recorded Chinese history and proceeds through to the contemporary PRC. As the bulk of evidence supporting a history of philanthropy is documentary in nature, most of the "artefacts" representing the period prior to the nineteenth century are texts or reproductions of texts that contain minor reference to charitable activities, including excerpts from well-known historical chronicles such as the Han Shu (Book of the Han Dynasty) and Sui Shu (Book of the Sui Dynasty). A number of lesser-known documents are also referenced, for example, imperial edicts related to disaster relief and stories from the Southern Song Dynasty that mention medical relief. Starting in the nineteenth century, corresponding to the late Qing Dynasty (1644-1911) and early Republican (1912-1949) periods, these predominantly textual displays become supplemented with a range of additional exhibits, including (reproduced) photographs, official (including legal) documents, books, newspaper articles, records relating to the operation of charities, and even personal effects formerly belonging to prominent philanthropists. The disparate nature of the objects displayed, and a lack of evidence for the early historical period, makes the museum's official narrative, presented via text panels in both Chinese and English, essential for giving the exhibition a sense of coherence and direction.

The account presented by the museum asserts that state-sponsored charitable activities began in the Western Zhou (1046-771 BCE) and Spring and Autumn (771-476 BCE) periods. The notion of "charity" used makes little distinction between "official" inter-state famine-relief activities and "civil" charitable activities undertaken by local clans and wealthy individuals. These activities are similarly described as evidence of an indigenous charitable tradition linked to the Confucian ethical responsibility of government and upright individuals to assist the needy. The blurring of lines between state/official and private dimensions informs the museum's entire narrative up to the present day.

The Han, Wei-Jin and Northern and Southern Dynasties (third century BCE to sixth century CE) are purported to have established nascent charitable institutions, while the expansion of civil charitable activities is attributed to the arrival of Buddhism in China during this period. The collection highlights the actions of individual "philanthropists", such as the wealthy Han 
Elaine Jeffreys (2018) Curating philanthropy and socialist governance: the Chinese Charity museum, Museums \& Social Issues, 13: 2, 78-93, DOI:10.1080/15596893.2019.16070 Published online 17 April 2019

Dynasty shepherd Bu Shi and the Jin Dynasty monk and doctor Fo Tucheng (232-348 CE). The main institutional example given is the "Six Diseases Hall", an institution established by aristocrats to help the poor and the sick as documented in a Southern Dynasty historical tract (the Nan Qi Shu). The earliest orphanage (attributed to the emperor of the Liao Dynasty) is dated to $521 \mathrm{CE}$.

However, the sparseness of evidence for charitable activities in these early times is apparent. The role of Buddhism is illustrated only with reference to photographs of the (sixth to tenth century) "Medical Prescription Grotto" (Yaofangdong) in the Longmen caves in Henan province - a UNESCO world heritage site encompassing a large collection of Buddhist rock temple carvings. The Grotto details 140 medical prescriptions that the museum narrative asserts were used to "treat the poor".

As the museum narrative moves through the Sui, Tang, Five, Song and Yuan Dynasties (609$1368 \mathrm{CE}$ ), the evidence and illustrations for charitable activities become more tangible, and especially for the Song Dynasty when civil charity is said to have become more prominent. Explanatory text panels recount efforts by regional officials and gentry to create foundling institutions to take in abandoned babies (due to the then-common practice of infanticide) and impoverished children. Other examples featured include the creation of a community aid society by Buddhist monks and nuns, "charity houses" to accommodate the destitute and disabled, medicine shops that offered inexpensive aid to the poor, and clan associations that assisted disadvantaged family members. Stories of individuals famed for their charitable acts flesh out the picture, including provincial magistrates, a Buddhist monk and well-known literati. Once again, such accounts are presented alongside reproductions of tracts on imperial government famine-relief policies and efforts to build granaries to guard against future famines.

The narrative finds firmer footing as it progresses through the Ming (1368-1644) and Qing Dynasties. Text reproductions illustrate the emergence of associations set up by the intelligentsia (chiefly scholars who had attended civil service examinations), which featured systems of dues for fee-paying members and provided assistance in organizing civil works, and weddings and medical care for poorer members. Reproductions of imperial edicts and narration in a sequence of text panels underscore the emergence of other often state- 
Elaine Jeffreys (2018) Curating philanthropy and socialist governance: the Chinese Charity museum, Museums \& Social Issues, 13: 2, 78-93, DOI:10.1080/15596893.2019.16070 Published online 17 April 2019

supported charitable institutions such as "porridge houses" (the equivalent of soup kitchens), "universal relief halls" (servicing the poor, sick, disabled and widowed) and similarly targeted "foster aid hospitals". The acts of individual "philanthropists" are also highlighted, including Tibetan architect Than Tong Gyalpo (1385-1464) who collected donations to build public works; the author Mao Xiang (1611-1693), who wrote a tract on famine relief and donated his possessions to famine victims; and the salt merchant Wang Yinggeng (1680 1742), who donated money to flood and drought victims and established porridge houses for the destitute. Other examples of state-civil interaction include the reproduction of imperial edicts praising the charitable efforts of south-eastern Chinese and Taiwanese businessmen during the disastrous northern famine of 1876-1879, and ordering rice to be dispatched to Wang Shuyuan's porridge house in 1902.

As the collection moves towards the end of the imperial era, it emphasizes the eclipsing of traditional philanthropy as the charity work of Western missionaries proliferated amid the socio-political turbulence of the late nineteenth century. Documents and photographs highlight the establishment of charitable institutions (schools, hospitals, orphanages and nurseries) by church organizations. For example, photographs are shown of Peter Parker and Andrew Patton Happer, American missionaries who, respectively, established Boji Hospital and Lingnan College in Guangzhou, as well as William E. Macklin, who established Gulou Hospital in Nanjing. The exhibition hints at the broader significance of these endeavours as supportive environments for a new generation of Western-influenced intellectuals, pointing to prominent Chinese alumni such as (future) revolutionary, Nationalist Party leader and President, Sun Yat-sen.

Despite the emphasis on Western religious charity, text panels also document examples of domestic philanthropists during this period. Particular emphasis is given to the activities of wealthy merchants in the Jiangsu region of south-eastern China, including those of the scholar-official Zhang Jian (see above), who established schools, colleges, foundling houses, nurseries and other charitable institutions in the Nantong area.

The flourishing of private charity in the late imperial era is portrayed as having continued during the Republican Era, until the Nationalist Party's defeat by the CCP in 1949. The Nationalist government is given credit via displays of newspaper articles for providing food- 
Elaine Jeffreys (2018) Curating philanthropy and socialist governance: the Chinese Charity museum, Museums \& Social Issues, 13: 2, 78-93, DOI:10.1080/15596893.2019.16070 Published online 17 April 2019

relief activities and refugee aid during a period of frequent military conflict and natural disasters, and raising public funds by issuing "tuberculosis-proof stamps" and creating official welfare lotteries. The Nationalist government is thereby inserted into a historical tradition of Chinese governments discharging their ethical duty of care for the underprivileged or dispossessed. But most of the museum exhibits for this period focus on demonstrating the formation and operation of private charitable organizations and fundraising activities.

Overall, the impression given is one of an overwhelmed and under-resourced Nationalist government's official public welfare activities being increasingly supplemented or replaced by private (including foreign) charitable work. Exhibits include fundraising letters and articles of association of charitable organisations, for example, nursing accreditation certificates from missionary hospitals. The collection highlights the emergence of numerous private charities, including the Shanghai Charity Society (1912), Anti-Kidnapping Society (1913), Chengdu Sino-Western Charity Society (1921), China Huayuan Famine Relief Commission (1921), Joint Association of Shanghai Charity Groups (1927), Shanghai Orphanage (1933), and Xinjiang Charity Association (1933). Although some of these charities were formed in coordination with Western missionaries, many were organized independently of external support.

The collection is, unsurprisingly, somewhat "silent" about the Mao era, when the CCP assumed responsibility for all available welfare services and most of the then existing charities were dismantled. A handful of photographs depict CCP leaders Mao Zedong and Zhou Enlai meeting with "people in need", including people affected by earthquakes.

Other than national leaders, the only individual featured during this period is Lei Feng, an iconic "PRC Good Samaritan". Lei Feng, a young peace-time soldier who died in an accident in 1962, became famous in 1963 when his life-story, encapsulated in a diary that celebrates Mao Zedong Thought and the "socialist" values of altruism, thrift and working hard for public goals, was promoted as a model of socialist citizenship through a national mobilization campaign. A subsequent annual "Lei Feng Day", rebadged in 2000 as "China Youth Volunteer Service Day", has ensured public familiarity with the Lei Feng "spirit" of selfless public service. In 2012-2013, the fiftieth anniversary of his death, Lei Feng featured in public 
Elaine Jeffreys (2018) Curating philanthropy and socialist governance: the Chinese Charity museum, Museums \& Social Issues, 13: 2, 78-93, DOI:10.1080/15596893.2019.16070 Published online 17 April 2019

service advertising promoting national unity and pride via themes of "commemoration", "volunteering" and "civic-mindedness" (Jeffreys, 2017b). The museum narrative therefore reiterates the more recent government depiction of Lei Feng as a symbol of an imagined but ongoing Chinese-socialist philanthropic tradition.

The final section of the museum collection relates to the post-1978 reform period. A key development emphasized is the advent in 1987 of the China Welfare Lottery, a national public fundraising initiative. Described as a "symbol of socialist culture", the lottery funds have assisted several hundred million people, especially the elderly, disabled, orphaned and poor. Exhibits include a photograph of President Xi Jinping (then Fujian party secretary) supervising the public drawing of entries to the lottery, which underscores contemporary government support for institutionalized philanthropy.

A sequence of exhibits, text panels and photographs highlight developments relevant to the government-sponsored expansion of philanthropy in the reform period. Some exhibits focus on the private philanthropy of senior leaders, showing original receipts of donations by former leaders such as Deng Xiaoping, Jiang Zemin and Hu Jintao. A series of photographs document the government's response to the SARS epidemic in 2003. Emphasis is also given to the proliferation of thrift-shop-style "charity supermarkets" - government-organized vehicles for distributing quality second-hand goods which were originally based on civil servant volunteering and now adopt a not-for-profit business model (Zou, Liu, \& Fang, 2016). Related exhibits refer to the Ministry of Civil Affairs' call in 2004 for such supermarkets to be established across the nation and a photograph of a charity supermarket in Nantong. Other exhibits document the evolution of PRC laws and regulations on philanthropy-volunteering, government and public involvement in the 2008 Sichuan and 2010 Qinghai earthquake relief efforts, the publication of a Philanthropy Index ranking Chinese cities in 2011, the inauguration of the China Charity Fair in 2012, and the introduction of the PRC's Charity Law, which came into effect on the opening day of the museum.

The exhibition also celebrates the activities of numerous government-organized charities and those of indigenous and international philanthropists, ranging from the super-rich and famous to anonymous donors and selfless public servants. Text panels and photographs document the fundraising achievements and beneficiaries of government-organized charities founded in and 
Elaine Jeffreys (2018) Curating philanthropy and socialist governance: the Chinese Charity museum, Museums \& Social Issues, 13: 2, 78-93, DOI:10.1080/15596893.2019.16070 Published online 17 April 2019

since the 1980s, including the China Children's Fund, China Handicapped Welfare Foundation, China Women's Development Foundation and China Foundation for Poverty Alleviation. The American entrepreneurs Andrew Carnegie and Bill Gates are featured for their famed massive donations to philanthropic causes. By way of comparison, Mother Teresa is celebrated for dedicating her life to help poor people and Hu Hansheng for his "Lei-Fengstyle" retirement practise of repairing bicycles and donating his earnings to charity. Wealthy Chinese living overseas, including in Hong Kong, Taiwan and Macau, are highlighted both for the extent of their donations and to demonstrate the greater "unity" of the Chinese nation.

Although the general message is that everyone is or can be a philanthropist by virtue of personal disposition rather than wealth, China's new generation of super-rich private entrepreneurs-cum-philanthropists are not represented in the collection. The reasons for this omission are unclear. It may reflect the difficulties of curatorial choice or the fact that biographies of such entrepreneurs would raise the vexed issues of private wealth accumulation and inequality, and potentially corruption and labour exploitation - that is, issues which a socialist state claims in theory to have overcome.

A concluding text panel reminds interested audiences that the exhibition demonstrates the universality and longevity of Chinese philanthropic culture, and the continued contributions of Chinese people from all walks of life to realizing the "dream" of rejuvenating China as a prosperous socialist superpower (articulated repeatedly by senior leaders such as President Xi Jinping). Other panels with erroneous interpretations of writings by the communist founding fathers, Karl Marx and Friedrich Engels, variously assure audiences that "caring for people in need" reflects the advancement of socialist society and the benevolence of the working people. A quotation from a 2015 speech by President Xi Jinping to the Central Poverty Alleviation and Development Work Conference adds that: "we need to research and learn from the successes of other countries, innovate China's philanthropic sector, stimulate the whole of society to engage in philanthropic activity, and encourage and support all kinds of enterprises, social organizations and individuals to participate in poverty alleviation strategies".

The museum collection and the socio-political narrative that frames it thus create a history for philanthropy as an enduring feature of Chinese culture, and a "natural" component of modern, 
Elaine Jeffreys (2018) Curating philanthropy and socialist governance: the Chinese Charity museum, Museums \& Social Issues, 13: 2, 78-93, DOI:10.1080/15596893.2019.16070 Published online 17 April 2019

socialist welfare provision. The museum's story equates the recently established core socialist values of harmony, equality, prosperity, civility and friendship, with revamped versions of traditional Chinese values embedded in Confucian, Buddhist and Daoist conceptions of humanness, benevolence and good government. It also elides the altered (as in governmentorganized) nature of PRC not-for-profits vis-à-vis their late imperial and Republican Era precursors. The aim is to encourage interested audiences of school children on school tours, and tourists on Nantong museum and cultural heritage tours, to participate with pride in a new but imagined longstanding holistic tradition of government-led and citizen-supported philanthropy.

\section{Concluding remarks}

The Chinese Charity Museum aims to educate and socialize interested audiences to be civicminded citizens by exhibiting a politically acceptable view of the history, evolution and role of Chinese philanthropy. There is high-level government support for the expansion of organized philanthropy in present-day China. However, there is no "official" public narrative that contextualizes the current political importance of philanthropy within the Chinese-PRC historical tradition. The museum collection shapes such a narrative within the boundaries of permissible PRC political discourses.

Visitors to the museum are presented with visions of a prosperous and powerful PRC based on a shared, albeit reconstructed, 3,000-year-long tradition of philanthropy. The collection presents the history of Chinese philanthropy as being rooted in individual and national values, and in continued government efforts to deliver a "good life" to its citizens. That history is portrayed as approaching maturity in the contemporary period. The socio-political narrative that frames the museum collection advances philanthropy as an enduring feature of Chinese culture, and as a "natural" component of modern life and social welfare provision.

The museum exhibits reflect considerable curatorial ingenuity and discipline, given that many scholars consider the subject of charity in traditional China to be an anomaly, and the early communist regime viewed charitable organizations in Marxist terms as expressions of elitist "feudal-capitalist" privilege (Smith, 2009, p. 1; Sun, 1994, p. 4). Contrary to claims that China has no "big" humanitarian philosophy, the museum collection mobilizes diverse 
Elaine Jeffreys (2018) Curating philanthropy and socialist governance: the Chinese Charity museum, Museums \& Social Issues, 13: 2, 78-93, DOI:10.1080/15596893.2019.16070 Published online 17 April 2019

artefacts and replicas of historical texts to hint at the evolution of an indigenous charitable tradition based in a fusion of Daoist and Buddhist beliefs, the activities of local clan and benevolent societies, and the Confucian ethical responsibility of governments and upright individuals to ensure social harmony by assisting those in need. The museum therefore guides the visitor to the presumption that contemporary Chinese philanthropy is rooted in core cultural values and practices, even as it blurs the distinctions between different philosophical conceptions of benevolence, kindness, compassion and philanthropy, and between different types of and motivations for "official" famine-relief activities and "civil" charitable activities undertaken by local elites.

The museum collection also blurs the distinction between Mao-era and reform-era conceptions of public versus private responsibilities for welfare provision, which serves an obvious political purpose. It suggests that certain types of private philanthropic initiatives are a natural extension of and complement to government welfare provision, eroding simpler former conceptions of the socialist cradle-to-grave welfare state. By reifying philanthropy as a lasting cultural undercurrent traversing both private and public spheres, the museum's narrative serves to legitimize the CCP's current governing approach to welfare provision, which simultaneously offers a state-controlled path to realizing the "dream" of modest prosperity for all citizens, while attempting to (re-)build notions of individual responsibility and self-guiding citizen behaviour.

\section{References}

Carrillo, B., Hood, J., \& Cadets, P. (Eds). (2017). Handbook of welfare in China. Cheltenham: Edward Elgar.

Chen, M., \& Fu, Q. (2015, November 30). Rang wenwu huo qilai, ba bowuguan dai huijia [Let heritage live: Bring the museum home!]. Xinhua Ribao. Retrieved from http://xh.xhby.net/mp2/html/2015-11/30/content_1342795.htm

Chen, Y-F. (2016, September 2). Dijiu jie zhonghua cishanjiang zai nantong banjiang [The Ninth China Charity Awards are held in Nantong]. Xinhua Ribao. Retrieved from http://xhrb.jschina.com.cn/mp3/pc/c/201609/02/c204848.html 
Elaine Jeffreys (2018) Curating philanthropy and socialist governance: the Chinese Charity museum, Museums \& Social Issues, 13: 2, 78-93, DOI:10.1080/15596893.2019.16070 Published online 17 April 2019

Chinese philanthropy museum opens to greet 1st Chinese Charity Day. (2016, September 2). Xinhua. Retrieved from http://www.xinhuanet.com/english/photo/201609/02/c_135654761.htm

Cooke, S. (2009). "Religious work": Governing religion in reform-era China. In E. Jeffreys (Ed.) China's governmentalities: Governing change, changing government. Abingdon: Routledge, pp. 125-150.

Denton, K. (2014). Exhibiting the past: Historical memory and the politics of museums in postsocialist China. Honolulu: University of Hawai'i Press.

Ding, D-W. (2011, September 21). Luoshi ba xiang gongcheng, shixian ba ge lingxian, xiang shuaixian jiben shixian xiandaihua kuobu qianjin [Implementing eight projects, achieving eight goals: Striding forward as pioneers to modernize]. Nantong Ribao.

Du, Y. (2016, March 2). 24-word core socialist values engraved on people's mind. People's Daily. Retrieved from http://en.people.cn/n3/2016/0302/c98649-9023926.html

Feng, C. (2017). The NGO Law in China and its impact on overseas funded NGOs.

Cosmopolitan Civil Societies: An Interdisciplinary Journal, 9(3), 95-105.

Gongmin daode jianshe shishi gangyao [Outline for building civic ethics]. (2001, October 24), Xinhua News Agency. Retrieved from http://www.people.com.cn/GB/shizheng/16/20011024/589496.html

Guanyu fazhan guomin jingji de di liu ge wunian jihua de baogao [Report on Sixth Five-year Plan on development of the national economy]. (2009, July 28). Guoshi Wang. Retrieved from http://www.hprc.org.cn/wxzl/wxys1/wnjj/diliugewnjh/200907/t20090728_16967_2.html

Guomin jingji he shehui fazhan di shiyi ge wunian guihua gangyao [Outline of the Tenth Five-Year Plan for the national economic and social development of the People's Republic of 
Elaine Jeffreys (2018) Curating philanthropy and socialist governance: the Chinese Charity museum, Museums \& Social Issues, 13: 2, 78-93, DOI:10.1080/15596893.2019.16070

Published online 17 April 2019

China]. (2001). Retrieved from

http://www.people.com.cn/GB/shizheng/16/20010318/419582.html

Ho, D. Y. (2018). Curating revolution: Politics on display in Mao's China. Cambridge, UK: Cambridge University Press.

Jeffreys, E. (2017a). Entrepreneurs, celebrities and charitable foundations: Elite philanthropy in China. In B. Carrillo, J. Hood \& P. Cadets (Eds). Handbook of welfare in China.

Cheltenham: Edward Elgar, pp. 317-337.

Jeffreys, E. (2017b). Understanding the Lei Feng revival: Evidence from a survey of Chinese students. China Media Research, 13(2), 54-66.

Jeffreys, E., \& Allatson, P. (2015). Celebrity philanthropy. Bristol, UK; Chicago, US: Intellect Press.

Jin, Y. (2016, July 29). Nantongshi tisheng xiandai minzheng jianshe lujing xuanze [Promoting modern civil construction in Nantong]. Zhongguo Shehuibao. Retrieved from http://www.jsmz.gov.cn/xwzx/mtgz/201607/2016-07-29_95414.htm

Law of the People's Republic of China on Protection of Cultural Relics. (2007). Retrieved from http://www.unesco.org/culture/natlaws/media/pdf/china/china_lawprotectionclt_entof

Li, J-H. (2015, November 30). Henhao de yanjiu Zhang Jian zai jianghai wenhua zhong zhongyao diwei [Do a good study of Zhang Jian's important role in Jianghai culture]. Nantong Ribao. Retrieved from http://www.zgnt.net/content/201511/30/content_2434750.htm

Liu, Y-Z. (2016, September 23). Guojia wenwuju juzhang liuyuzhu: Dali tuijin 'yidai yilu' wenhua yichan baohu guanli liyong de guoji jiaoliu hezuo [Liu Yuzhu, Director of the State Administration of Cultural Heritage: Vigorously promote international exchange and cooperation regarding “One Belt, One Road” cultural heritage protection and management. 
Elaine Jeffreys (2018) Curating philanthropy and socialist governance: the Chinese Charity museum, Museums \& Social Issues, 13: 2, 78-93, DOI:10.1080/15596893.2019.16070

Published online 17 April 2019

Zhongguo Wenwubao. Retrieved from

http://ccrnews.com.cn/index.php/Index/content/id/62020.html

Lu, T. (2015). Museums in China: Power, politics and identities. Abingdon: Routledge.

McDonald, S. (2003). Museums, national, postnational and transcultural identities. Museum and Society, 1(1), 1-16.

Message, K., \& Witcombe, A. (2015). Introduction: Museum theory, an expanded field. In. K. Message \& A. Witcombe (Eds.). The international handbooks of museum studies, 1 , pp. xxxv-lxiii.

Nantong. (2016). Baidu Baike. Retrieved from

http://baike.baidu.com/subview/1225/19109520.htm?fromtitle=\%E5\%8D\%97\%E9\%80\%9A $\%$ E5\%B8\%82\&fromid=2208115\&type=syn\#9

National People's Congress. (2016a). Zhonghua renmin gongheguo cishanfa [Charity Law of the People's Republic of China]. Retrieved from http://www.npc.gov.cn/npc/dbdhhy/12_4/2016-03/21/content_1985714.htm

National People's Congress. (2016b). Jingwai feizhengfuzuzhi guanlifa [Law of the People's Republic of China on the Management of Foreign Non-Governmental Organizations' Activities within Mainland China]. Retrieved from http://www.chinalawtranslate.com/2016foreign-ngo-law/?lang=en

Pan, Y. (2012, May 25). Cishan: Guizai zeren, guizai guan'ai [Charity: Valuing responsibility and care]. Renmin Ribao. Retrieved from http://theory.people.com.cn/GB/49154/49156/17983275.html

People's Daily. (1946-2010). Jinbao dianzi chuban zhongxin. Beijing: Oriprobe Information Services. Retrieved from www.oriprobe.com 
Elaine Jeffreys (2018) Curating philanthropy and socialist governance: the Chinese Charity museum, Museums \& Social Issues, 13: 2, 78-93, DOI:10.1080/15596893.2019.16070 Published online 17 April 2019

Ren, Y-B. (2011, November 16). Cishan bowuguan heyi luohu nantong? [Why is the Chinese Charity Museum being built in Nantong?]. Nantong Ribao.

Simon, K. (2013). Civil society in China. Oxford, UK: Oxford University Press.

Smith, J. H. (2009). The art of doing good: Charity in late Ming China. Berkeley; Los Angeles: University of California Press.

State Council. (2014). Guowuyuan guanyu cujin cishan shiye jiankang fazhan de zhidao yijian [Guidance from the State Council on promoting the healthy development of philanthropy]. Retrieved from http://www.gov.cn/zhengce/content/201412/18/content_9306.htm

Sun, Y-M. (1994, February 24). Wei cishan zhengming [Rehabilitating charity]. Renmin Ribao, p. 4.

Tao, Y-Q. (2011, May 25). Nantong choujian Zhonghua cishan bowuguan [Nantong to build Chinese Charity Museum]. Gongren Ribao.

Wang, J-H, \& Xu, N. (2012, July 20). Bowuguang yu chengshi fazhan [Museums and urban development]. Zhongguo Wenwubao.

What is philanthropy. (2017). Philanthropy Australia. Retrieved from http://www.philanthropy.org.au/tools-resources/sector-overview/

Wu, R-H, Jiang, X., Zhou, R-J, \& Feng, G. (2016, May 19). Woguo 85\% bowuguan mianfei kaifang, meinian yue 7 yi renci canguan [ $85 \%$ of China's museums are free entry to the public, with around 700 million visitors each year]. Renmin Ribao. Retrieved from http://society.people.com.cn/n1/2016/0519/c1008-28362954.html

Xu, Y-H. (2012, February 2). Jiakuai tuijing wenhua chanye xiangmu, quanmian luoshi wenhua jianshe gongcheng [Accelerate culture industry projects, fully implement cultural 
Elaine Jeffreys (2018) Curating philanthropy and socialist governance: the Chinese Charity museum, Museums \& Social Issues, 13: 2, 78-93, DOI:10.1080/15596893.2019.16070 Published online 17 April 2019 construction plans. Nantong Ribao. Retrieved from http://www.zgnt.net/content/201202/02/content_1995569.htm

Yuan, X-J., \& Huang, K. (2016, September 1). Zhishan zhishan, rang cishan jingshen yongzhu [Good intentions, let the spirit of charity last forever]. Nantong Ribao. Retrieved from http://www.zgnt.net/content/2016-09/01/content_2479913.htm

Zhang, L. (2013) China's traditional cultural values and national identity. Carnegie-Tsinghua Center for Global Policy, 21 November. Retrieved from http://carnegietsinghua.org/2013/11/21/china-s-traditional-cultural-values-and-nationalidentity-pub-53613

Zhang, W-T. (2016, September 26). Bingcheng gongxiang linian dali fazhan cishan shiye [Uphold the concept of sharing and vigorously developing the philanthropic sector].

Zhongguo Shehuibao. Retrieved from http://www.mca.gov.cn/article/zwgk/mzyw/201609/20160900001864.shtml

Zhang, X. (2012, June 6). Quanguo zhengxie zai jing zhaokai tian banli xieshanghui [Chinese People's Political Consultative Conference holds a proposal management meeting in Beijing]. Zhongguo Shehuibao. Retrieved from http://www.mca.gov.cn/article/zwgk/mzyw/201206/20120600318343.shtml

Zhang, Y-Z. (2011, May 16). Wo guo cishan lingyu shoujia guojiaji zhuanti bowuguan jiang luohu Jiangsu Nantong [China's first national-level, charity-focused museum to be built in Nantong]. Zhongguo Shehuibao.

Zhao, J-L. (2016, September 1). Zhonghua cishan bowuguan kai guan bing juban "zhonghua cishan jiang" banjiang dianli [Chinese Charity Museum opens and holds the "China Charity Awards" ceremony]. Xinhua News Agency. Retrieved from

Zhonggong zhongyang guanyu zhiding guomin jingji he shehui fazhan dishi ge wunian jihua de jianyi [Proposal from the Central Committee of the Communist Party of China on formulating the Tenth Five-Year Plan for National Economic and Social Development]. 
Elaine Jeffreys (2018) Curating philanthropy and socialist governance: the Chinese Charity museum, Museums \& Social Issues, 13: 2, 78-93, DOI:10.1080/15596893.2019.16070 Published online 17 April 2019 (2000, October 18). Xinhua News Agency. Retrieved from http://www.hprc.org.cn/wxzl/wxysl/wnjj/dishgewnjh/200907/t20090728_16945.html

Zhonghua renmin gongheguo guomin jingji he shehui fazhan di ba ge wunian guihua (zhaiyao) [Eighth Five-Year Plan for the National Economic and Social Development of the People's Republic of China (summary)]. (1991). Retrieved from http://www.hprc.org.cn/wxzl/wxysl/wnjj/dibagewnjh/200907/t20090729_16985_10.html

Zhonghua renmin gongheguo guomin jingji he shehui fazhan di qi ge wunian guihua (zhaiyao) [Seventh Five-Year Plan for the National Economic and Social Development of the People's Republic of China (summary)]. (1986). Retrieved from http://www.hprc.org.cn/wxzl/wxysl/wnjj/diqigewnjh/200907/t20090728_16971_14.html

Zhonghua renmin gongheguo guomin jingji he shehui fazhan di shisan ge wunian guihua gangyao [Outline of the Thirteenth Five-Year Plan for the National Economic and Social Development of the People's Republic of China]. (2016). Retrieved from http://www.hprc.org.cn/wxzl/wxysl/wnjj/ssw/201604/t20160405_370468.html

Zhonghua renmin gongheguo guomin jingji he shehui fazhan di shiyi ge wunian guihua gangyao [Outline of the Eleventh Five-Year Plan for the National Economic and Social Development of the People's Republic of China]. (2006). Retrieved from http://www.hprc.org.cn/wxzl/wxysl/wnjj/diyigewnjh/200907/t20090728_16933_12.html Zou, Y-M., Liu, Q. and Fang, X-J. (2016, October 22). Jieli shequ yingzao, zhongguo cishan chaoshi mou bian [Leveraging the community to change China's charity supermarkets]. Nanfang Zhoumo. Retrieved from http://www.infzm.com/content/120361 